admissions. It should be noted that the defendants did not request severance in Delli Paoli. One may thus argue that the Court has not yet approved the prevailing view that denial of motions for severance lies within the trial court's discretion unless it clearly appears that the jury relied on an admission in convicting co-defendants. ${ }^{22}$ Thus it may still be possible, where a defendant moves for severance, for a federal court to adopt Judge Frank's suggestion that severance be the price for reception of post-conspiracy admissions. ${ }^{23}$ Such a rule would result in separate trials only where the prosecution feels the admissions sufficiently important to justify the expense and inconvenience of separate prosecution. ${ }^{24}$ In any event, where post-conspiracy admissions are put in evidence at joint trial, administrative expense should not deter severance; risk of injustice would seem a heavy price for economy of administration.

${ }^{22}$ Consult note 3 supra. Prejudicial reliance may be shown in several ways. A court may look to the extent to which the admission itself implicates co-defendants. Hale v. United States, 25 F.2d 430 (C.A.8th, 1928). Or the issue may turn on the ease with which the admission could be considered separately from the other evidence. Consult note 6 supra. For courts presuming jury reliance despite the placebo, lack of prejudice may be shown by the existence of overwhelming independent evidence of guilt. People v. Skelly, 409 III. 613, 100 N.E.2d 915 (1951) ; People v. Fisher, 249 N.Y. 419, 164 N.E. 336 (1928).

${ }^{23}$ United States v. Delli Paoli, 229 F.2d 319, 324 (1956).

${ }^{24}$ Several state statutes have made severance mandatory in felony cases. Statutes collected in A.L.I. Code of Criminal Procedure 239-41 (proposed final draft, 1930). Under such a statute, Colorado courts have required the defendant on his severance motion to show by affidavit the existence of evidence admissible as to a co-defendant and inadmissible as to the movant. Garcia v. People, 88 Colo. 267, 295 Pac. 491 (1931). Inasmuch as the prosecution's case may not be fully available to the defendant on pre-trial discovery, such an interpretation imposes an unfair burden. Consult Pre-Trial Disclosure in Criminal Cases, 60 Yale L.J. 626 (1951). The most compelling argument against discovery, i.e., that it encourages fabricated defenses, seems inappropriate with regard to the placebo situation, since the evidence concerned is not properly part of the prosecution's case against the movant. Further, content disclosure need not be mandatory, the primary concern of the movant being the existence and possible use at joint trial of this species of evidence. Perhaps simple allegation of the existence of implicating admissions should suffice to force the prosecution to declare its intentions with regard to introducing such evidence on joint trial. Also, it should be noted that these declarations are often introduced as testimony, usually beyond the purview of discovery procedure.

\title{
COMPETITORS' RIGHT TO ENJOIN UNLICENSED PROFESSIONAL PRACTICE
}

Professional men, ${ }^{1}$ facing invasion of their fields by unlicensed competitors, have sought injunctive relief frequently in recent years. ${ }^{2}$ While the trend is

I Profession, as used in this comment, refers to a wide range of occupations. The common factor is the requirement of governmental licensing based on personal qualifications.

'In Ilegal Practice of Professions-Licensed Practitioner's Right to Enjoin, 11 So. Calif. L. Rev. 476 (1938), it is stated that the first injunction granted against unlicensed professional practice was in Dworken v. Apt. House Owners Ass'n, 38 Ohio App. 365, 176 N.E. 577 (1931). 
to grant this relief, injunctions have often been denied, and there are serious questions as to whether allowing competitors to enjoin unlicensed competition ${ }^{3}$ is consistent with the traditional rules concerning appropriateness of injunctive relief and standing to enjoin.

Although, at first glance, it would seem that several adequate remedies at law are available to both individuals and public officials, it would be erroneous to hold injunctive relief inappropriate on this ground. ${ }^{4}$ The existence of damages, an essential element of a legal suit, might seem capable of adequate proof on the ground that unlicensed competition must cause some loss of business to a licensee, assuming that not all of the defendant's customers would forego service were his talents not available. But it is not clear that it is the plaintiff in any particular suit, rather than some other licensee, who suffered a loss of business as a result of the defendant's activities. Thus, the existence of damage is speculative and the amount, of course, is even more so. Inability to prove the amount of damages is one of the classic factors in establishing the inadequacy of legal remedies. ${ }^{5}$

One might argue that a group of licensees in a class action could adequately establish damages. If the class consists of all practitioners whom customers of the defendant might have otherwise patronized, it could be presumed that the total volume of the defendant's business was the amount of business lost by the plaintiff class. However, while this argument may establish the existence of damage, the amount remains speculative. If the defendant had not been in practice, some of his customers might have foregone service entirely, while others might have patronized other unlicensed practitioners. In addition, there is no way of determining how the damages collected are to be apportioned among the plaintiffs involved.

The possibility of continued infraction by the unlicensed defendant, necessitating multiple suits, may be another factor indicating inadequacy of individual actions at law. Full assessment of damages might deter continued infraction, but only if those damages could be measured. Thus, inability to measure damages appears to establish inadequacy of individual legal remedies and may explain also why no damage actions were found in the unlicensed competition area.

Two basic forms of legal remedies are available to public officials. ${ }^{6}$ In most

${ }^{3}$ This comment does not touch upon the question of what practices constitute unlicensed practice. In regard to the unauthorized practice of law, consult Symposium on the "Unauthorized Practice of the Law" Controversy, 5 Law \& Contemp. Prob. No. 1 (1938).

'The basic principle of equity that injunctions may not be granted where an adequate remedy at law exists had its origin in English Chancery practice. Consult Cook, Cases and Materials on Equity (4th ed., 1948); McClintock, Equity 103 (2d ed., 1948).

${ }^{5}$ Ibid.

'Criminal prosecution and the information in the nature of quo warranto. In the field of unlicensed practice of law, the additional remedy of contempt citations has been used, often with a statutory basis. Consult Sanders, Procedures for the Punishment or Suppression of Unauthorized Practice of Law, 5 Law \& Contemp. Prob. 135, 140 (1938). 
states, practice in violation of the licensing statutes is a crime. ${ }^{7}$ Although criminal prosecution has been used successfully against unlicensed practitioners, ${ }^{8}$ the remedy has several disadvantages. Most important is the fact that the prosecution is not conducted by the truly interested party-the licensed practitioner. Public prosecutors, concerned with the prosecution of more drastic and well publicized crimes, may be reluctant to move. ${ }^{9}$ Also, it has been urged that the public is not convinced of the seriousness of unlicensed practice and that this attitude may be reflected in jury verdicts. ${ }^{10}$ Finally, unlicensed practice is normally a mere misdemeanor, involving only small fines which may often be paid without seriously impeding continued unlicensed operation. ${ }^{11}$

Another public remedy is the information in the nature of quo warranto. ${ }^{12}$ This action is instituted by the state alone or on the relation of an interested party. Although the form is criminal, ${ }^{13}$ the sanction imposed is the cease-anddesist order-more effective than imposition of small fines. This form of action does not require a jury trial, one aspect of criminal prosecutions. Although quo warranto has been used effectively against unlicensed competition, ${ }^{14}$ it has not been used as extensively as might be expected. This may result from lawyers' unfamiliarity with the remedy or from courts' failure to hold that the availability of quo warranto precludes the use of equity. This failure may in turn indicate that courts have abandoned the adequacy-at-law test where, as in the case of quo warranto, the available legal remedy is not substantially different from the injunction.

The traditional rule against enjoining crimes has been the basis for denying injunctions in a few unlicensed practice cases. ${ }^{15}$ This rule may be merely

${ }^{7}$ Id., at 136 , for example, where it is stated that the unlicensed practice of law was a misdemeanor in 39 states.

${ }^{8}$ State v. Chamberlain, 132 Wash. 520, 232 Pac. 337 (1925); People v. Alfani, 227 N.Y. 334, 125 N.E. 671 (1919) ; People v. Goldsmith, 224 App. Div. 707, 229 N.Y.Supp. 896 (1st Dep't, 1928).

${ }^{\ominus}$ Beardsley, Lay Encroachments, 36 Com. L. J. 275 (1931). It would seem, however, that refusal of public officials would establish the inadequacy of the legal remedy.

${ }^{10} \mathrm{Ibid}$. However, since unlicensed practice is normally a misdemeanor, jury trials are sometimes unavailable to the defendant. People v. Weil, 237 App. Div. 118, 260 N.Y.Supp. 658 (1st Dep't, 1932).

${ }^{11}$ Statutes vary greatly on the point. Consult Sanders, op. cit. supra note 6, at 136. Consult also People v. Laman, 277 N.Y. 368, 14 N.E.2d 439 (1938).

${ }^{13}$ This form of action has developed from the English writ of Quo Warrante and serves the same basic purpose, prevention of the exercise of powers not authorized by law, as required. It is the form usually employed to prohibit unauthorized exercise of franchise.

${ }^{13}$ Consult note 7 supra.

${ }^{11}$ People v. Merchants Protective Corporation, 189 Cal. 531, 209 Pac. 363 (1922); State v. Perkins, 138 Kan. 899, 28 P.2d 765 (1934); State v. Retail Credit Men's Ass'n, 163 Tenn. 450, 43 S.W.2d 918 (1931).

${ }^{15}$ State v. Maltby, 108 Neb. 578, 188 N.W. 175 (1922) ; People v. Universal Chiropractors' Ass'n, 302 Ill. 228, 134 N.E. 4 (1922). 
another articulation of the adequacy-at-law test, since a criminal penalty might be thought an adequate legal remedy. Whatever the rationale, the prohibition against enjoining crimes is not absolute, since it is usually held that equity will enjoin criminal activity if an independent ground for injunctive intervention exists. ${ }^{16}$ On this basis the injunction has been successfully used by both public officials ${ }^{17}$ and private plaintiffs. ${ }^{18}$

Where public officials bring the action, a mere showing of a public nuisance, i.e., a danger to the public, is sufficient to sustain injunctive relief. ${ }^{19}$ However, in the case of private complainants, traditional rules require a showing of "special" damage. Most courts in the unlicensed competition cases hold that the "special" damage requirement necessitates merely a showing of the existence of damage..$^{20}$ For the individual complainant this requirement is subject to all the difficulties of establishing the existence of damage in actions at law. ${ }^{21}$ However, in representative or class suits, proving the existence of damage, as contrasted with the amount, is no problem..$^{22}$ Some courts require that the "special" damage be different from that suffered by the general public, ${ }^{23}$ but since the injury in these cases is loss of business attracted by the unlicensed competitor, the damage would seem to be necessarily different from that sustained by the general public, which is not in competition with the

16 "It is fundamental that courts of equity do not have jurisdiction to enjoin the commission of a crime, but courts have recognized that if grounds for equitable intervention are present an injunction may issue even though the conduct objected to is also a crime." Burden v. Hoover, 9 Ill.2d 114, 116, 137 N.E.2d 59, 60 (1956).

I7 State v. Smith, 43 Ariz. 131, 29 P.2d 718 (1934); State ex rel. Marron v. Compere, 44 N.M. 414, 103 P.2d 273 (1940) ; People v. Lamen, 277 N.Y. 368, 14 N.E.2d 439 (1938). In some states, statutory provision for injunctions by public officials exist. Consult Sanders, Procedures for the Punishment or Suppression of Unauthorized Practice of Law, 5 Law \& Contemp. Prob. 135, 156 (1938). See also State v. Fray, 214 Iowa 53, 241 N.W. 663 (1932); Ky. State Board of Dental Examiners v. Payne, 213 Ky. 382, 281 S.W. 188 (1926).

${ }^{18}$ Bump v. Barnett, 235 Iowa 308, 16 N.W.2d 579 (1944); Burden v. Hoover, 9 Ill.2d 114, 137 N.E.2d 59 (1956); Auerbacher v. Wood, 139 N.J. Eq. 599, 53 A.2d 800 (1947).

1" Note 17, supra.

${ }^{20}$ New Jersey State Bar Ass'n v. Northern New Jersey Mortgage Associates, 22 N.J. 184, 123 A.2d 498 (1956); Goldsmith v. Jewish Publishing Co., 118 Misc. 789, 195 N.Y. Supp. 37 (1922) ; MacBeth v. Gerbers, Inc., 72 R.I. 102, 48 A.2d 366 (1946).

mew Jersey State Bar Ass'n v. Northern New Jersey Mortgage Associates, 22 N.J. 184, 123 A.2d 498 (1956).

New Jersey State Bar Ass'n v. Northern New Jersey Mortgage Associates, 22 N.J. 184, 123 A.2d 498 (1956) ; Auerbacher v. Wood, 139 N.J. Eq. 599, 53 A.2d 800 (1947); Washington State Bar Ass'n v. Washington Ass'n of Realtors, 41 Wash.2d 697, 251 P.2d 619 (1952). Contra: Burden v. Hoover, 9 Mll.2d 114, 137 N.E.2d 59 (1956) ; Fitchette v. Taylor, 191 Minn. 582, 254 N.W. 910 (1934) ; Mo. Veterinary Medical Ass'n v. Glison, 230 S.W.2d 169 (Mo. App., 1950) ; Unger v. Landlords' Management Corp., 114 N.J.Eq. 68, 168 Atl. 229 (1933).

${ }^{23}$ Wollitzer v. Nat. Title Guaranty Co., 148 Misc. 529, 266 N.Y. Supp. 184 (1933) ; Hexter Title and Abstract Co. v. Grievance Committee, etc., 142 Tex. 506, 179 S.W.2d 946 (1944). This rule has also been applied to injunctions against competitors outside the profession. Consult N.Y., N.H.\&H.R. Co. v. Deister, 253 Mass. 178, 148 N.E. 590 (1925). 
defendant. However, a few courts deny injunctions to licensees on the ground of failure to show special damage, ${ }^{24}$ thus failing to analyze the requirement, or failing to raise a presumption of damage, even in class suits.

Assuming competitors' ability to show the existence of injury from unlicensed competition, there remains the question of whether a legal right has been injured; failure to show the existence of such right has been the most frequently-used basis for denial of relief. Many courts have characterized licenses as a property right, and the loss of business to unlicensed competition as property damage. ${ }^{25}$ But any competition is economically injurious to other competitors, at least in the short run. In our competitive economy there cannot be a legal right to be free from all competition. The legal right of the licensee can only be the right to be free from unlawful competition, which includes unlicensed competition.

The right to be free from unlicensed competition has been characterized as a franchise, ${ }^{26}$ to be protected by injunction. ${ }^{27}$ Some courts, however, have drawn a distinction between exclusive franchises-the holders of which have a cause of action if the right to engage in the same or similar activities is granted to another-and non-exclusive franchises, which are granted to all qualified applicants. This distinction, recognized by many courts, has sometimes been used to deny relief to holders of non-exclusive franchises. ${ }^{28}$ It is obvious that the holder of an exclusive franchise has a valuable interestfreedom from all competition-infringement of which justifies judicial action. But non-exclusive licensing statutes also reduce competition, though to a lesser extent. This reduction of competition may be quite important in areas where, as in the professions, standards of education and skill are stringent. The value of the right to operate in such restricted fields seems clear. Some courts have implicitly recognized this fact, although verbally retaining the

${ }^{24}$ MacBeth v. Gerbers, Inc., 72 R.I. 102, 48 A.2d 366 (1946); Wollitzer v. Nat. Title Guaranty Co., 148 Misc. 529, 266 N.Y. Supp. 184 (1933) ; Goldsmith v. Jewish Publishing Co., 118 Misc. 789, 195 N.Y.Supp. 37 (1922). In New Jersey State Bar Ass'n v. Northern New Jersey Mortgage Associates, 22 N.J. 184, 123 A.2d 498 (1956), standing was denied the individual plaintiff on this basis, but granted to the class.

${ }^{20}$ Smith v. Illinois Adjustment Finance Co., 326 Ill.App. 654, 63 N.E.2d 264 (1945); Paul v. Stanley, 168 Wash. 371, 12 P.2d 401 (1932); Ezell v. Ritholz, 188 S.C. 39, 198 S.E. 419 (1938); Dvorine v. Castelberg Jewelry Corp., 170 Md. 661, 185 Atl. 562 (1936); Sloan v. Mitchell, 113 W.Va. 506, 168 S.E. 800 (1933); New Jersey State Bar Ass'n v. Northern New Jersey Mortgage Associates, 22 N.J. 184, 123 A.2d 498 (1956).

${ }^{29}$ A franchise is usually defined as a privilege or immunity, existing by grant of a government, which does not belong to the public by common right. Black's Law Dictionary (4th ed., 1951).

${ }^{27}$ Unger v. Landlords' Management Corp., 114 N.J.Eq. 68, 168 Atl. 229 (1933); Smith v. Illinois Adjustment Finance Co., 326 Ill.App. 654, 63 N.E.2d 264 (1945) ; Paul v. Stanley, 168 Wash. 371, 12 P.2d 401 (1932); Sloan v. Mitchell, 113 W.Va. 506, 168 S.E. 800 (1933); Childs v. Smeltzer, 315 Pa. 9, 171 Atl. 883 (1934).

${ }^{23}$ Unger v. Landlords' Management Corp., 114 N.J.Eq. 68, 168 Atl. 229 (1933) ; Mosig v. Jersey Chiropodists, Inc., 122 N.J. Eq. 382, 194 Atl. 248 (1937). 
exclusive-franchise distinction, by creating a category of franchises "exclusive as against unlicensed competition." result, but lacks the candor of admitting that the court has abandoned the exclusive-franchise distinction.

The basic attack on the right of licensees to restrain unlicensed competition has come in the form of a flat denial of any legal right to be free from even unlawful competition. The argument is that licensing statutes were not enacted for the benefit of licensed practitioners, but for the protection of the general public. ${ }^{30}$ Some courts making this argument have recognized that many of the licensing statutes were proposed and guided to enactment by qualified practitioners, with the underlying purpose of limiting competition for their own benefit. ${ }^{31}$ These lobbyists' motives may well have been the "intent" of the active supporters of these statutes in the legislatures. A court, however, can hardly be urged to follow such "intent," and in fact courts have equated the legislative "intent" with the general policy arguments advanced to justify licensing statutes to disinterested legislators and to the general public-protection of the public from the inexpert services of unlicensed practitioners. ${ }^{32}$

Some courts have conceded that the purpose of licensing statutes is protection of the public, but have, nevertheless, granted injunctions against unlicensed practice at the suit of private individuals. ${ }^{33}$ Since an individual practitioner has no right to be free from competition in general, the legal right recognized by the granting of relief must be the right to be free of competition made illegal by the licensing statute. Thus, the statute which is said to be intended for the public benefit only is held to create a legal interest in licensed practitioners. This anomaly persists unless it is recognized that a statute may create legal rights in individuals for the purpose of protecting the general public. ${ }^{34}$

If it is conceded that private plaintiffs can only sue as public protectors, the question remains of whether a showing of damage should be required to

${ }^{90}$ Unger v. Landlords' Management Corp., 114 N.J.Eq. 68, 168 Atl. 229 (1933). This theory was earlier utilized in a utility case-the field in which the "exclusive" distinction seems to have been developed. Citizens Electric Co. v. Lackawanna \& Wyo. Power Co., 255 Pa. 145, 99 Atl. 462 (1916).

${ }^{30}$ Mosig v. Jersey Chiropodists, Inc., 122 N.J.Eq. 382, 194 Atl. 248 (1937) ; Delaware Optometric Corp. v. Sherwood, - Del. -, 128 A.2d 812 (1957); MacBeth v. Gerbers Inc., 72 R.I. 102, 48 A.2d 366 (1946); Auerbacher v. Wood, 139 N.J. 599, 53 A.2d 800 (1947). Often, the principle is put in terms of a lack of a property interest, Mo. Veterinary Medical Ass'n. v. Glisan, 230 S.W.2d 169 (Mo. App., 1950); Depew v. Wichita Ass'n of Credit Men, 142 Kan. 403, 49 P.2d 1041 (1935).

"1 Mosig v. Jersey Chiropodists, Inc., 122 N.J.Eq. 382, 194 Atl. 248 (1937).

s2 Supra note 30.

$\approx$ Burden v. Hoover, 9 Ill.2d 114, 137 N.E.2d 59 (1956).

st Roosevelt Field v. Town of North Hempstead, 84 F.Supp. 456 (E.D. N.Y., 1949). 
allow a plaintiff to qualify for this role. Some courts seem to feel that no such showing of damage should be necessary. ${ }^{35}$ Thus, in one case, where a real estate association was enjoined from unlicensed practice of the law, the court said:

When an action such as this is brought on behalf of the public, it is not one in which the right of an individual plaintiff is concerned. Consequently, no pecuniary or property interest of the plaintiff need be involved. ...36

The New Jersey Supreme Court has said that group suits by bar associations would be allowed without a showing of specific injury. ${ }^{37}$ And in that same case the court also held that individual attorneys "have no standing to complain in the absence of specific injury. . .."38 All the cases on which the court relied as abandoning the damage requirement were representative suits. $^{39}$ These cases might rest on a presumption of damage arising from the fact that all the competitors whom defendant might have damaged are represented as plaintiffs; the cases do not, however, explicitly recognize such a presumption.

The allowance of injunctions without a showing of damage to the plaintiff has been confined to suits by bar associations. ${ }^{40}$ The distinction between law and other professions has been justified on the ground that the right to practice law is of ancient origin and is, therefore, a franchise or property right, while the right to engage in other professions, sometimes based on statute, has not yet achieved the stature of "property." 11 But a recent interest created by statute may be as valuable to the holder as any other. It has also been argued that since a court is intimately concerned with the practice of law, its authority should be greater in that field than in other professions. Lawyers, as "officers of the court," are simply exercising the court's authority when they sue to enjoin unlicensed practice. ${ }^{42}$ However, it would seem that

${ }^{25}$ New Jersey State Bar Ass'n v. Northern New Jersey Mortgage Associates, 22 N.J. 184, 123 A.2d 498 (1956) ; Auerbacher v. Wood, 139 N.J. 599, 53 A.2d 800 (1947); Washington State Bar Ass'n v. Washington Ass'n of Realtors, 41 Wash.2d 697, 251 P.2d 619 (1952).

${ }^{38}$ Washington State Bar Ass'n v. Washington Ass'n of Realtors, 41 Wash.2d 697, 700, 251 P.2d 619, 621 (1952).

${ }^{37}$ New Jersey State Bar Ass'n v. Northern New Jersey Mortgage Associates, 22 N.J. 184, 123 A.2d 498 (1956).

${ }^{38}$ Id., at 196, 504.

${ }^{39}$ Consult note 35, supra. But see Burden v. Hoover, 9 Ill.2d 114, 137 N.E.2d 59 (1956), holding in a suit by five licensed chiropractors, that unlicensed practice infringes the rights of licensees so as to enable the latter to enjoin, with no talk of a showing of injury.

${ }^{10}$ Consult note 35 supra.

“Lipman v. Forman, 138 N.J. Eq. 556, 49 A.2d 236 (1946) ; Delaware Optometric Ass'n v. Sherwood, - Del. -, 122 A.2d 424 (1956); Smith v. Illinois Adjustment Finance Co., 326 IIl.App. 654, 63 N.E.2d 264 (1945); Burden v. Hoover, 7 Ill.App.2d 296, 129 N.E.2d 463 (1955), rev'd 9 Ill.2d 114, 137 N.E.2d 59 (1956).

${ }^{2}$ Wheat v. Hilkey, 148 Kan. 60, 79 P.2d 865 (1938). 
the ability of a court to bring contempt proceedings ${ }^{43}$ should satisfy any special role the court has to play in the legal profession; "officers of the court" would seem to have no role beyond calling the court's attention to unlicensed practice so that contempt proceedings could be initiated. In dealing with other questions raised in suits for injunctive relief against unlicensed competitors the courts have displayed a tendency to disregard the distinction between law and the other professions; ${ }^{44}$ it may well be that this trend will carry over into the question of damages.

Elimination of the damage requirement in competitors' suits to enjoin unlicensed practice might appear desirable, at first glance. Even without a showing of damage, each case will present a controversy, in the sense that the parties will have adverse interests which they feel to be worth litigating; collusion appears no more likely with competitors who cannot show damage than with those who can. Nor are competitors who have not shown damage unjustly enriched by decrees in their favor, since no damages are awarded. However, if a limitation to class suits is desired in order to prevent harass-

${ }^{43}$ People ex rel. Ill. State Bar Ass'n v. The Peoples Stock Yards State Bank, 344 III. 462, 176 N.E. 901 (1931) ; People ex rel. Chicago Bar Ass'n v. Goodman, 366 Ill. 346, 8 N.E.2d 941 (1937).

"In determining the direction of the law in this area, it is most meaningful to examine a series of cases from a single jurisdiction. In People ex. rel. Shepardson v. Universal Chiropractor's Ass'n, 302 IIl. 228, 134 N.E. 4 (1922), the Illinois Supreme Court refused, in a suit by the Attorney General, to enjoin the operations of fifty-two unlicensed chiropractors. The court relied on People v. Love, 298 Mll. 304, 131 N.E. 809 (1921), and held that chiropractic is not a nuisance per se. But that prior case does not seem to have considered whether unlicensed practice under a valid licensing statute is a nuisance.

However, contempt actions were successfully prosecuted for the unlicensed practice of law in People ex rel. Chicago Bar Ass'n v. Goodman, 366 Ill. 346, 8 N.E.2d 941 (1937), and People ex rel. Chicago Bar Ass'n v. Novotny, 386 Ill. 536, 54 N.E.2d 536 (1944). The next step was the granting of an injunction on behalf of a bar association in People ex rel. Chicago Bar Ass'n v. United Taxpayers of America, 312 Ill.App. 243, 38 N.E.2d 349 (1941), and again in People ex rel. Chicago Bar Ass'n v. Kellogg, 338 Ill.App. 618, 88 N.E.2d 519 (1949), and People ex rel. Chicago Bar Ass'n v. Clausen, 1 Ml.App.2d 140, 117 N.E.2d 321 (1953).

The right of an individual attorney to enjoin unlicensed competition was affirmed on the basis of the franchise theory, but the decision distinguished between law and other professions. Smith v. Illinois Adjustment Finance Co., 326 Ill.App. 654, 63 N.E.2d 264 (1945). This distinction was abandoned by the Illinois Supreme Court in Burden v. Hoover, 9 ml.2d 114,137 N.E.2d 59 (1956). Expressly overruling the Chiropractors Ass' $n$ case, the court held that individual chiropractors too had standing to enjoin unlicensed competitors, since no material distinguishing features exist between attorneys' licenses and other professional licenses. The standing of the plaintiffs was based on both their property interest and the benefit to the public of restraint of unlicensed practice.

A series on New Jersey cases show a definite movement toward liberalization of damage requirements, but no abandonment of the distinction between law and other professions. Unger v. Landlords' Management Corp., 114 N.J.Eq. 68, 168 Atl. 229 (1933); Mosig v. Jersey Chiropodists, Inc., 122 N.J.Eq. 382, 194 Atl. 248 (1937); Lipman v. Forman, 138 N.J.Eq. 556, 49 A.2d 236 (1946); Auerbacher v. Wood, 139 N.J.Eq. 599, 53 A.2d 800 (1947); New Jersey State Bar Ass'n v. Northern New Jersey Mortgage Associates, 22 N.J. 184, 123 A.2d 498 (1956). 
ment by a multiplicity of individual suits, this might well be achieved by the damage requirement; few, if any, individual plaintiffs could show damage, while a proper class could be presumed to have sustained damage.

In any event, the damage requirement will not be abandoned completely in the unlicensed practice field. As long as courts confine to competitors the right to enjoin unlicensed practice, some sort of damage requirement is operating; competitors are more likely to have suffered damage than other plaintiffs. But, if plaintiffs are regarded as public protectors only, the rationale for a limitation to competitors of the right to enjoin is unclear. If individual suits are to be allowed, there would seem to be no reason why individual non-competitor plaintiffs could not protect the public as well as competitors. However, to allow non-competitors to sue would require complete abandonment of the damage requirement-a step which courts may well be unwilling to take. Nor would it seem necessary to take this step in order to achieve adequate public protection; the motivation for a non-competitor to sue will seldom arise.

\section{STATE STATUTES: CONSTITUTIONAL SUBJECT-TITLE AND AMENDATORY REQUIREMENTS}

No act hereafter passed shall embrace more than one subject, and that shall be expressed in the title ... and no law shall be revived or amended by reference to its title only, but the law revived, or the section amended, shall be inserted at length in the new act. 1

This and similar constitutional provisions have been used with increasing frequency but with diminishing success in attacking the validity of legislation. Since, as Justice Frankfurter has remarked, "today cases not resting on statutes are reduced almost to zero," ${ }^{22}$ such provisions are important tools for the lawyer who must deal with legislation. This comment will survey the Illinois decisions in order to appraise the likelihood of successfully attacking statutes by means of such a constitutional provision.

\section{SUBJECT-TITLE PROVISION}

The adoption of a constitutional requirement limiting each act to a single "subject" which must be described in the title resulted from dissatisfaction with the early English and American practice of enacting statutes without titles. $^{3}$ The generally expressed purposes of such a provision are several:

${ }^{1}$ IIl. Const. Art. IV, $§ 13$. Similar provisions appear in the constitutions of other states. E.g., Cal. Const. Art. IV, \$24; Ind. Const. Art. 4, \$19; Fla. Const. Art. III, \$16; Md. Const. Art. III, \$29.

${ }^{2}$ Frankfurter, Some Reflections on the Reading of Statutes, 47 Col. L. Rev. 527 (1947).

${ }^{3}$ The titles to early statutes were supplied by a clerk after enactment, indicating his understanding rather than that of the legislature. Where titles were supplied by the 